\title{
COMPARATIVE TRENDS IN LOG POPULATIONS IN NORTHERN ARIZONA MIXED-CONIFER AND PONDEROSA PINE FORESTS FOLLOWING SEVERE DROUGHT
}

\author{
Joseph L. Ganey ${ }^{1,2}$ and Scott C. Vojta ${ }^{1}$
}

\begin{abstract}
Logs provide an important form of coarse woody debris in forest systems, contributing to numerous ecological processes and affecting wildlife habitat and fuel complexes. Despite this, little information is available on the dynamics of log populations in southwestern ponderosa pine (Pinus ponderosa) and especially mixed-conifer forests. A recent episode of elevated tree mortality in these forest types in northern Arizona caused a pulse in log inputs as dead trees broke and fell. We documented changes in these log populations from 2004 to 2009 in an earlier paper. Here, we extended that work to evaluate changes in log abundance and volume between 2009 and 2014, compare trends in log abundance and volume between this period and the preceding 5 -year period, estimate overall change in log abundance and volume over the period from 2004 to 2014, and describe temporal relationships between log abundance and changes in populations of snags (standing dead trees) during the study. Trends in log populations differed between forest types. Increases in log abundance were more widespread and larger in magnitude in mixed-conifer forest than in ponderosa pine forest. Over the entire 10-year study period, log abundance increased by $52 \%$ and $30 \%$ in mixed-conifer and ponderosa pine forest, respectively. Most of that increase occurred in the first 5 years, especially in ponderosa pine forest. Log abundance and volume continued to increase from 2009 to 2014 in mixed-conifer forest, whereas these parameters showed little change in ponderosa pine forest over this period. Log abundance lagged snag abundance, which peaked in 2007 but remained elevated in 2012 relative to pre-2007 levels in both forest types. Thus, log abundance may continue to increase as those snags break and fall. The ultimate magnitude and duration of this drought-mediated pulse in log inputs to these systems thus remains unknown. Understanding how these systems respond to drought-related mortality pulses may aid forest ecologists and managers charged with adapting forest management strategies in an era of changing climate.
\end{abstract}

Resumen.-Los troncos proporcionan una importante fuente de residuos de leña en los sistemas forestales, contribuyendo a numerosos procesos ecológicos y afectando el hábitat de la vida silvestre y de los complejos de energía. A pesar de esto, hay poca información disponible sobre la dinámica de las poblaciones de troncos al sudoeste del pinar ponderosa (Pinus ponderosa) y especialmente en los bosques de coníferas mixtas. Un episodio reciente de aumento de la mortalidad de árboles en estos bosques, al norte de Arizona, incrementó el aporte de troncos ya que los árboles muertos se quebraron y cayeron. Documentamos cambios en estas poblaciones de troncos desde el año 2004 al 2009 en un artículo anterior. En esta investigación ampliamos aquel trabajo para evaluar los cambios en la abundancia y en el volumen de troncos entre el año 2009 y el 2014, para comparar las tendencias en la abundancia y el volumen de los troncos entre este período y los últimos 5 años, estimar el cambio general en el volumen y la abundancia de los troncos durante el período del año 2004 al 2014, y describir las relaciones temporales entre la abundancia de troncos y los cambios en las poblaciones de árboles muertos en pie durante el estudio. Las tendencias en las poblaciones de troncos difirieron de acuerdo a los tipos de bosque. El aumento en la abundancia de troncos fue más generalizado y de mayor magnitud en el bosque de coníferas mixtas que en el bosque de pino ponderosa. Durante el período total de 10 años de estudio, la abundancia de troncos aumentó un $52 \%$ y un $30 \%$ en el bosque de coníferas mixtas y en el bosque de pinos ponderosa, respectivamente. La mayor parte de ese aumento se produjo en los primeros cinco años, especialmente en el bosque de pino ponderosa. El volumen y la abundancia de los troncos continuó aumentando desde el año 2009 al 2014 en el bosque de coníferas mixtas, a la vez que estos parámetros mostraron poca variación en el bosque de pino ponderosa durante el mismo período. La abundancia de troncos retrasó la abundancia de árboles muertos, que alcanzó su punto máximo en 2007, manteniéndose elevado en 2012 en comparación a los niveles anteriores al año 2007, en ambos tipos de bosques. De este modo, la abundancia de troncos podría seguir aumentando a medida que los árboles muertos en pie se quiebren y caigan. La duración y la magnitud del ritmo de ingreso de troncos a estos sistemas, mediado por la sequía, aún se desconocen. La comprensión de cómo estos sistemas responden a los ritmos de mortalidad relacionados con las sequías puede ser de utilidad para los ecólogos y los administradores forestales encargados de adaptar las estrategias de manejo forestal en una era marcada por el cambio climático.

Logs (large down woody material) provide an important form of coarse woody debris (CWD) in forest systems (Maser and Trappe
1984, Harmon et al. 1986, Bull et al. 1997). Decaying logs serve as a source of nutrients for forest soils, provide microsites for numerous

${ }^{1}$ USDA Forest Service, Rocky Mountain Research Station, Flagstaff, AZ.

${ }^{2} \mathrm{E}$-mail: jganey@fs.fed.us 
species of wood-dwelling organisms, and contribute to both water and carbon storage dynamics (McComb and Lindenmayer 1999, Butler et al. 2002, Woldendorp and Keenan 2005). Logs, especially large logs, provide foraging and food storage sites, den sites, travel routes, and hiding cover for numerous wildlife species (Bull et al. 1997), and amounts and types of CWD affect surface fuel loads and fire behavior in forested sites (Brown et al. 2003, Hoffman et al. 2012, Stevens-Rumann et al. 2012, Forrestel et al. 2015).

The population of logs present at a site reflects the balance between log formation and loss of logs through decay and/or disturbance processes (Shorohova and Kapitsa 2015). Log formation occurs as a discrete event through falling of live or standing dead trees (snags) or breakage of large limbs or tops of trees and snags. Some background level of log formation is always occurring, but background rates can differ widely among forest systems and successional stages (Dunn and Bailey 2012, Acker et al. 2013), and disturbance processes such as wildfire, high wind events, bark beetle outbreaks, or drought can create discrete pulses in log formation (Dunn and Bailey 2015, Peterson et al. 2015).

One such pulse occurred recently in southwestern mixed-conifer and ponderosa pine forests following an episode of drought-mediated tree mortality (Negrón et al. 2009, Ganey and Vojta 2011, Kane et al. 2014). Much of this mortality resulted from a climatically extreme year (2002) embedded within a longer-term drought. This extreme year featured unusually high temperatures coupled with unusually low precipitation, resulting in one of the driest years in the past 1400 years (Weiss et al. 2009). The resulting tree mortality peaked from approximately 2002 to 2004 (Ganey and Vojta 2011, Hoffman et al. 2012, Kane et al. 2014) and resulted in a pronounced pulse of log inputs to these systems as dead trees broke and fell (Ganey and Vojta 2012a).

Types and amounts of CWD affect numerous ecosystem processes, wildlife habitat, fuels complexes, and forest regeneration and successional trajectories (Maser and Trappe 1984, Harmon et al. 1986, Bull et al. 1997). Because of these strong effects, understanding the magnitude, progression, and duration of pulses of CWD following disturbance events is important for managers (Roccaforte et al.
2012). Such information largely is lacking for southwestern forest systems, however. We have limited information on CWD dynamics following input pulses caused by wildfire (Chambers and Mast 2005, Passovoy and Fulé 2006, Roccaforte et al. 2012, Stevens-Rumann et al. 2012) or bark beetles in southwestern ponderosa pine (Pinus ponderosa) forests (Hoffman et al. 2012, Chambers and Mast 2014) but know little about CWD dynamics following disturbance events in other southwestern forest types, including mixed-conifer forest, and generally lack information on the dynamics of log populations in all of these forest types.

We have been studying populations of snags (since 1997) and logs (since 2004) in fixed plots in northern Arizona mixed-conifer and ponderosa pine forests. The resulting data provided a unique opportunity to study the progression of this pulse in CWD inputs. We previously used data from these plots to report on patterns of tree mortality (Ganey and Vojta 2011), trends in snag populations (Ganey and Vojta 2005, 2012b, 2014), and changes in $\log$ populations between 2004 and 2009 (Ganey and Vojta 2012a). Here, we extend the analyses from Ganey and Vojta (2012a) to ask 2 questions: Did the rapid increases in $\log$ abundance and volume observed in these systems from 2004 to 2009 persist from 2009 to 2014? And were trends in log populations similar between these forest types, both over the entire 10-year study period and especially from 2009 to 2014? Although our focus was on changes in log populations, we also incorporated data on snag populations and changes in those populations to describe temporal relationships between snag and log populations. Thus, we were interested in whether log populations continued to increase as rapidly in these systems from 5 to 10 years post-disturbance as they did in the first 5 years post-disturbance (Ganey and Vojta 2012a), and whether these different forest types behaved similarly with respect to the ubiquity, magnitude, and timing of this pulse in log inputs. This information is relevant to our understanding of the magnitude, longevity, and variability in droughtmediated legacies in these systems, as well as to how these forests may be impacted by changing climates (Millar et al. 2007, Seager et al. 2007, Allen et al. 2010). 

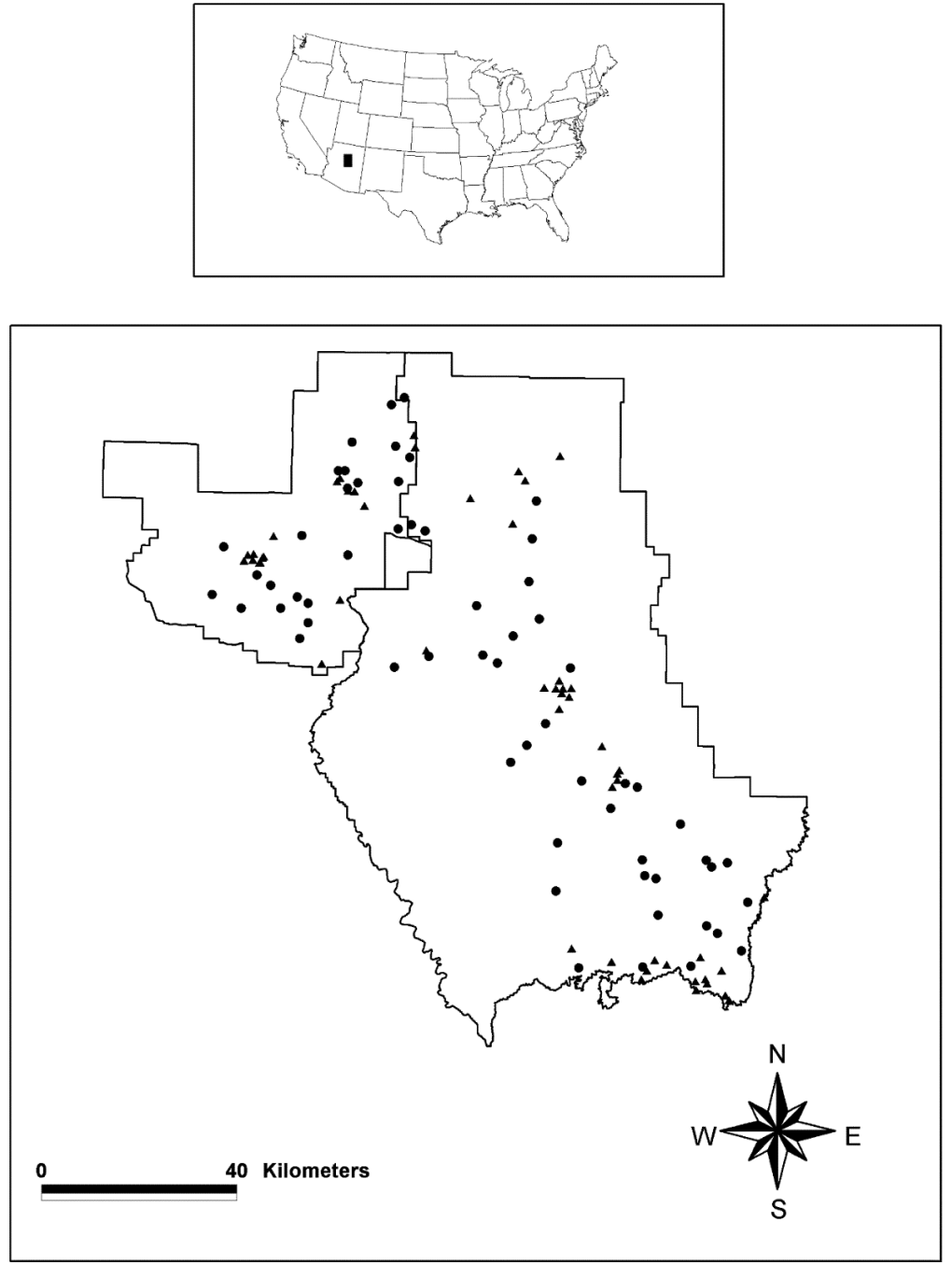

Fig. 1. Location of the study area (black box, top) in northern Arizona, USA, and locations of snag-monitoring plots within the study area (bottom). Plots were located in the Coconino (right) and Kaibab (left) national forests, north central Arizona. Plots in ponderosa pine forest $(n=60)$ are indicated by circles, and plots in mixed-conifer forest $(n=53)$ by triangles.

\section{STUDY AREA}

Our study area encompassed approximately 73,000 ha within the Coconino and Kaibab national forests in north central Arizona (Fig. 1). We focused on 2 major forest types within this area. Mixed-conifer forests were dominated numerically by Douglas-fir (Pseudotsuga menziesii), white fir (Abies concolor), and ponderosa pine, which together accounted for approximately $90 \%$ of the total trees sampled in this forest type. Other species included Gambel oak (Quercus gambelii), quaking aspen
(Populus tremuloides), and limber pine (Pinus flexilis), in that order of frequency. Ponderosa pine accounted for over $90 \%$ of trees in ponderosa pine forest. Gambel oak also was relatively common (approximately $8 \%$ of total trees by frequency); and alligator juniper (Juniperus deppeana), Douglas-fir, quaking aspen, limber pine, pinyon pine (Pinus edulis), Utah juniper (Juniperus osteosperma), and oneseed juniper (Juniperus monosperma) were present at some sites within this forest type.

Topography varied widely within the study area, ranging from valley bottoms to elevated 
TABLE 1. Sampling regimes for snags and logs in northern Arizona mixed-conifer and ponderosa pine forests. Logs were sampled in subplots within larger snag plots.

\begin{tabular}{llc}
\hline Structure & Years sampled & Plot size (ha) \\
\hline Snags & $1997,2002,2007,2012$ & 1.00 \\
Logs & $2004,2009,2014$ & 0.09 \\
\hline
\end{tabular}

plains and steep mountain and canyon slopes. Elevation ranged from 1778 to $2720 \mathrm{~m}$ at plots sampled (see below) within the study area. Plots sampled encompassed the entire elevational range of mixed-conifer and ponderosa pine forests within this area, from the transition zone between pinyon-juniper woodland and ponderosa pine at lower elevations to the ecotone between mixed-conifer and Engelmann spruce (Picea engelmanni)-corkbark fir (Abies lasiocarpa var. arizonica) forests at higher elevations. Plots sampled included both commercial forest lands and administratively reserved lands such as wilderness and other roadless areas, and encompassed a wide range of forest structural conditions. Density of trees $\geq 20 \mathrm{~cm}$ diameter at breast height (sampled in 2004) ranged from 78 to 489 trees $\cdot \mathrm{ha}^{-1}(\bar{x}=274.8, \mathrm{SE}=$ 13.1) in mixed-conifer forest and from 11 to 689 trees $\cdot \mathrm{ha}^{-1}(\bar{x}=237.6, \mathrm{SE}=18.1)$ in ponderosa pine forest. Basal area ranged from 7 to $52 \mathrm{~m}^{2} \cdot \mathrm{ha}^{-1}(\bar{x}=25.8, \mathrm{SE}=1.4)$ in mixed-conifer forest and from 1 to $44 \mathrm{~m}^{2}$. $\mathrm{ha}^{-1}(\bar{x}=20.8, \mathrm{SE}=1.2)$ in ponderosa pine forest (Ganey and Vojta 2011). Most stands were uneven in age, so that tree age varied widely both within and among plots.

\section{Methods}

\section{Field Sampling}

We sampled snags and logs within 113 plots located randomly (Ganey and Vojta $2005)$ within mixed-conifer $(n=53$ plots $)$ and ponderosa pine forests ( $n=60$ plots). Both timing and spatial scale of sampling differed between snag and log populations. We sampled snags at 5-year intervals beginning in 1997 and $\log _{s}$ at similar intervals beginning in 2004 (Table 1). The snag plots were each 1 ha in area $(100 \times 100 \mathrm{~m})$, but we sampled logs in a 0.09 -ha subplot $(30 \times 30 \mathrm{~m})$ within each larger plot due to time constraints and the greater abundance of logs relative to snags (Ganey and Vojta 2012a).
We sampled all logs $\geq 20 \mathrm{~cm}$ in large-end diameter and $\geq 2 \mathrm{~m}$ in length within each 0.09-ha subplot on each sampling occasion. The minimum large-end diameter of $20 \mathrm{~cm}$ for logs was selected to be consistent with minimum dbh for snags sampled (see below). We recorded large- and small-end diameter (nearest $\mathrm{cm}$ ) and length (nearest $0.1 \mathrm{~m}$ ) for all logs sampled, and computed mean diameter as the average of large- and small-end diameters. For logs that extended across plot boundaries, we measured length and diameter only for the portion within those boundaries. We marked all logs in 2004 and 2009 with numbered metal tags to allow for individual identification and monitoring of fates of individual logs. Tag loss was extensive by 2014, however, as tags fell out of decaying wood or were pulled out and moved or hidden by animals. Therefore, we discontinued marking of logs in 2014, made no attempt here to analyze fates of individual logs, and focused instead on overall change in log populations.

We sampled all snags $\geq 2 \mathrm{~m}$ in height and $\geq 20 \mathrm{~cm}$ in diameter at breast height (dbh) within each 1-ha plot on each sampling occasion. The $20-\mathrm{cm}$ minimum dbh reflected study objectives related to wildlife habitat and the perception that smaller snags were less useful to wildlife, especially cavity-nesting birds (Cunningham et al. 1980, Ganey and Vojta 2004, Chambers and Mast 2005, 2014). We marked all snags with numbered metal tags, allowing us to track fates of individual snags and identify new snags when resampling plots.

Note that application of minimum size criteria meant that not all logs and snags or all surface fuels were sampled. All logs sampled corresponded to $>1000$-h fuels as defined by fuels managers (Brown et al. 2003), but not all 1000 -h fuels were sampled (we did not sample pieces $<2 \mathrm{~m}$ in length or with a large-end diameter between $7.6 \mathrm{~cm}$ and $20 \mathrm{~cm}$ ). Consequently, our inferences here are restricted to populations of larger snags and logs, and do not extend to overall snag or log populations or to entire fuel complexes.

\section{Changes in Log Populations}

We updated the analyses in Ganey and Vojta (2012a) to evaluate changes in log populations between 2009 and 2014. We estimated log abundance $\left(\operatorname{logs} \cdot \mathrm{ha}^{-1}\right.$; note that we use "abundance" rather than density throughout 
to indicate number of logs [or snags] per unit area to avoid potential confusion with wood structural density) and volume $\left(\mathrm{m}^{3} \cdot \mathrm{ha}^{-1}\right.$; computed based on mean diameter and log length, assuming cylindrical shape) separately by forest type and year. Although our primary focus was on changes occurring from 2009 to 2014, we presented empirical data for all years sampled for comparative purposes.

Data distributions for log abundance and volume frequently were highly skewed, particularly in ponderosa pine forest (Ganey and Vojta 2012a). Because of these highly skewed distributions, standard location measures for central tendency such as the mean and median did not adequately describe these populations. Ganey and Vojta addressed this issue by presenting both means and medians, as well as ranges in the data (Table 1 of Ganey and Vojta 2012a). Herein we address this issue differently, using Huber's M-estimator, a generalized maximum-likelihood estimator that provides robust estimates of central tendency in distributions containing outliers (Huber and Ronchetti 2009) for all estimates of central tendency. We estimated this parameter and associated 95\% bias-corrected confidence intervals using 1000 bootstrap iterations (Efron and Tibshirani 1993). All subsequent references to mean values refer to Huber's M-estimator.

The skewed distributions for log abundance and volume also precluded standard hypothesis tests. Consequently, we evaluated bootstrapped, bias-corrected confidence intervals around Huber's M-estimates to assess significance for parameters describing changes in log populations over time. We assumed that confidence intervals that did not overlap zero denoted significant changes for the indicated parameter and time period. Robust estimation of all parameters was accomplished using IBM SPSS Statistics v23 (IBM SPSS Statistics, IBM Corp., Armonk, NY, 2015).

\section{Relationships Between Log and Snag Populations}

Overall change in log abundance from 2004 to 2014 varied widely among plots, with some plots showing large increases in log numbers and other plots showing decreases. This change reflected the balance between inputs of new logs and loss of old logs to decay processes or to disturbance such as fuelwood harvest or fire. We were not able to estimate loss of logs from these plots because extensive tag loss made it impossible to follow fates of individual logs, but we were able to estimate several parameters describing inputs to log populations using data from inventories of marked snags. We estimated snag abundance in 1997, 2002, 2007, and 2012, providing an assay of abundance of existing snags, a potential source for logs, at 4 points in time during the study. We estimated loss of snags from these populations during the 5-year periods between snag inventories (1997-2002, 2002-2007, and 2007-2012) as the number of marked snags falling between times $t$ and $t+5$. Similarly, we estimated snag gain (an index of tree mortality) over these 5 -year periods as the number of new snags recruited between times $t$ and $t+5$.

Our indices of snag loss and gain underestimate inputs to log and snag populations. Breakage of standing trees or snags can create logs in addition to falling snags; falling trees can directly create logs without ever entering the snag population; and some trees that died and entered the snag populations after time $t$ may have fallen before time $t+5$, and thus were never counted. We were unable to quantify the magnitude of these biases. Nonetheless, these indices provided the best available information on snag abundance, gain, and loss, and we used them to qualitatively explore temporal relationships between changes in log populations and snag populations. We focused this evaluation on mean levels for all indices within forest type, rather than on individual plots. We again used Huber's M-estimator to estimate mean values, as described above, and units for all parameters were snags per hectare $\left(\right.$ snags $\left.\cdot \mathrm{ha}^{-1}\right)$.

\section{Results}

\section{Changes in Log Abundance}

We sampled 609, 809, and 934 logs in mixed-conifer plots in 2004, 2009, and 2014, respectively, and 233, 267, and 303 logs in ponderosa pine plots in those years. Although total numbers of logs increased in both forest types from 2009 to 2014, variation in $\log$ abundance among plots was pronounced (see confidence intervals in Table 2).

Mean log abundance increased significantly (i.e., the confidence interval around the estimate of change in log abundance did not 
TABLE 2. Log abundance $\left(\operatorname{logs} \cdot \mathrm{ha}^{-1}\right)$ and volume $\left(\mathrm{m}^{3} \cdot \mathrm{ha}^{-1}\right)$ by year in northern Arizona mixed-conifer and ponderosa pine forests, based on repeated sampling of 53 and 60 plots, respectively.

\begin{tabular}{|c|c|c|c|c|c|}
\hline \multirow[b]{2}{*}{ Parameter } & \multirow[b]{2}{*}{ Year } & \multicolumn{2}{|c|}{ Mixed-conifer } & \multicolumn{2}{|c|}{ Ponderosa pine } \\
\hline & & $\mathrm{M}^{\mathrm{a}}$ & $95 \% \mathrm{CI}^{\mathrm{b}}$ & $\mathrm{M}^{\mathrm{a}}$ & $95 \% \mathrm{CI}^{\mathrm{b}}$ \\
\hline \multirow[t]{3}{*}{ Abundance } & 2004 & 123.1 & 102.3 to 145.4 & 31.0 & 20.1 to 45.1 \\
\hline & 2009 & 165.2 & 138.5 to 191.2 & 37.0 & 30.0 to 43.7 \\
\hline & 2014 & 186.9 & 157.1 to 219.4 & 39.2 & 30.8 to 51.2 \\
\hline \multirow[t]{3}{*}{ Volume } & 2004 & 60.7 & 45.1 to 76.8 & 8.4 & 4.8 to 14.6 \\
\hline & 2009 & 72.5 & 55.2 to 90.8 & 8.9 & 5.5 to 15.1 \\
\hline & 2014 & 76.9 & 58.7 to 98.1 & 8.6 & 6.1 to 12.8 \\
\hline
\end{tabular}

aHuber's M-estimator, a generalized maximum-likelihood estimator that yields robust estimates of central tendency in distributions containing outliers (Huber and Ronchetti 2009). Estimates were computed from 1000 bootstrap iterations.

bBias-corrected confidence interval based on 1000 bootstrap iterations.

TABLE 3. Within-plot change in log abundance $\left(\operatorname{logs} \cdot \mathrm{ha}^{-1}\right)$ and volume $\left(\mathrm{m}^{3} \cdot \mathrm{ha}^{-1}\right)$ by time period in northern Arizona mixed-conifer and ponderosa pine forests, based on repeated sampling of 53 and 60 plots, respectively.

\begin{tabular}{|c|c|c|c|c|c|}
\hline \multirow[b]{2}{*}{ Parameter } & \multirow[b]{2}{*}{ Period } & \multicolumn{2}{|c|}{ Mixed-conifer } & \multicolumn{2}{|c|}{ Ponderosa pine } \\
\hline & & $\mathrm{M}^{\mathrm{a}}$ & $95 \% \mathrm{CI}^{\mathrm{b}}$ & $\mathrm{M}^{\mathrm{a}}$ & $95 \% \mathrm{CI}^{\mathrm{b}}$ \\
\hline \multirow[t]{3}{*}{ Abundance } & 2004-2009 & 33.4 & 22.8 to 46.4 & 6.5 & 3.9 to 9.9 \\
\hline & 2009-2014 & 27.5 & 16.4 to 38.7 & 0.4 & -4.2 to 5.1 \\
\hline & 2004-2014 & 61.9 & 44.4 to 81.0 & 7.4 & 2.2 to 14.5 \\
\hline \multirow[t]{3}{*}{ Volume } & 2004-2009 & 10.1 & 5.7 to 15.9 & 0.5 & 0.0 to 0.9 \\
\hline & 2009-2014 & 8.8 & 1.2 to 16.0 & -0.5 & -2.2 to 0.6 \\
\hline & 2004-2014 & 15.8 & 7.7 to 27.1 & 0.2 & -1.1 to 1.6 \\
\hline
\end{tabular}

aHuber's M-estimator, a generalized maximum-likelihood estimator that yields robust estimates of central tendency in distributions containing outliers (Huber and Ronchetti 2009). Estimates were computed from 1000 bootstrap iterations.

${ }^{b}$ Bias-corrected confidence interval based on 1000 bootstrap iterations.

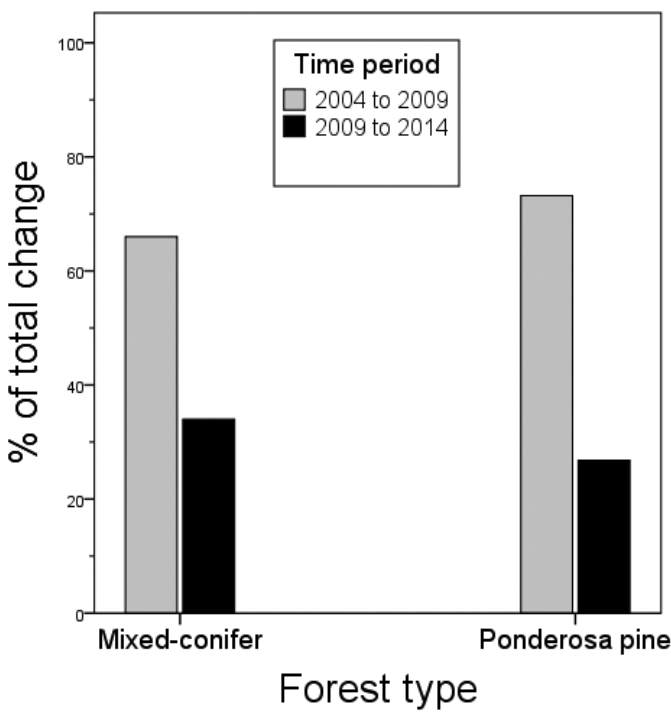

Fig. 2. Percent of total change in log abundance over a 10 -year period in northern Arizona mixed-conifer and ponderosa pine forest by 2 consecutive 5 -year time periods (2004 to 2009 and 2009 to 2014). Log inputs appeared to peak rapidly following drought in both forest types, but especially in ponderosa pine forest. overlap zero) between 2009 and 2014 in mixed-conifer forest but not in ponderosa pine forest (Table 3). Over the entire period from 2004 to 2014 , mean $\log$ abundance increased by $51.8 \%$ and $29.7 \%$ in mixed-conifer and ponderosa pine forest, respectively (Table 2 ). Most of that change occurred in the first 5-year sampling interval, however, especially in ponderosa pine forest (Fig. 2).

Across the 10-year sampling period, log abundance increased in almost $80 \%$ of mixedconifer plots versus only $45 \%$ of ponderosa pine plots (Fig. 3). The proportion of plots showing increased $\log$ abundance declined between subsequent 5-year sampling periods in both forest types (Fig. 3), however, and log numbers decreased from 2009 to 2014 on 11 plots in mixed-conifer forest $(21 \%)$ and 16 plots in ponderosa pine forest (27\%; Fig. 3). These decreases indicated that losses of logs due to factors such as fire, decay, and fuelwood harvest exceeded log inputs in these plots. We were unable to estimate log losses directly or assign those losses to particular causal factors, however, because we were unable to track fates of individual logs (see above). Fire was a contributing factor in log losses in some plots but 


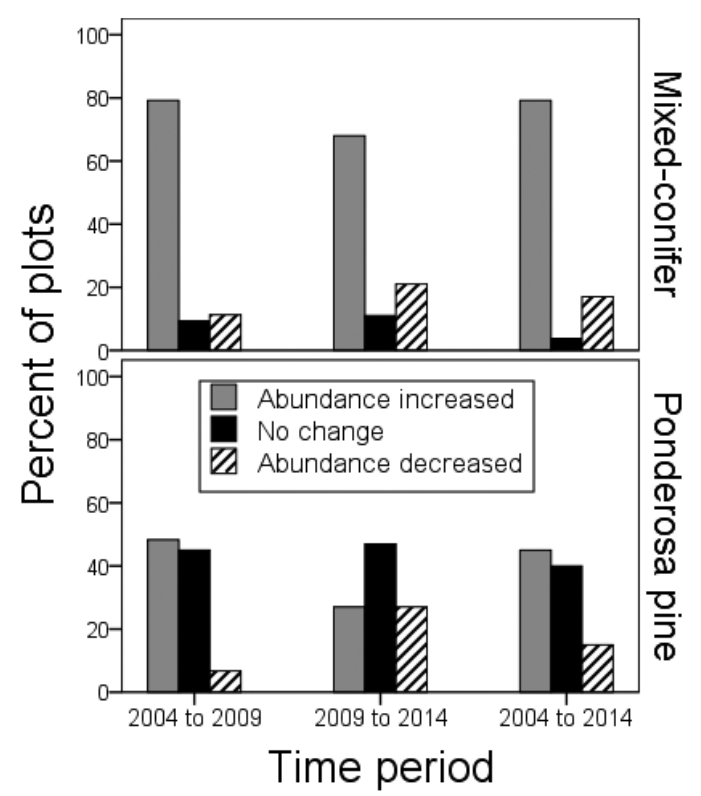

Fig. 3. Percent of plots in northern Arizona mixedconifer ( $n=53$ plots) and ponderosa pine ( $n=60$ plots) forest where $\log$ abundance increased, decreased, or stayed the same between sampling occasions, by 3 time periods. Increases in $\log$ abundance were more widespread in mixed-conifer than in ponderosa pine forest.

did not affect enough plots to explain all decreases observed, as prescribed fires burned only 1 and 3 plots and wildfires burned only 4 and 3 plots in mixed-conifer and ponderosa pine forest, respectively, during this period.

\section{Changes in Log Volume}

Log volume also increased significantly between 2009 and 2014 in mixed-conifer forest but not in ponderosa pine forest (Table 3). As with abundance, the pace of change slowed relative to the preceding 5 -year period. Over the period from 2004 to 2014 , mean log volume increased by $26.7 \%$ in mixed-conifer forest but remained largely unchanged in ponderosa pine forest $(+2.4 \%$; Table 2$)$.

Log populations were dominated by smalldiameter logs, with $50 \%$ of all logs being $\leq 23.5 \mathrm{~cm}$ in midpoint diameter in both forest types across all years and $75 \%$ being $\leq 32.5 \mathrm{~cm}$ in midpoint diameter. This relatively small diameter for most logs explained the large difference in magnitude of change between log abundance and log volume, because most logs contributed little volume (mean $=0.23 \mathrm{~m}^{3}$, CI 0.22 to $0.24 \mathrm{~m}^{3}$ ).

\section{Relationships Between Log and Snag Populations}

Snag gain (indexing tree mortality) peaked during the period from 2002 to 2007 in both forest types (Table 4; Fig. 4), then returned to pre-peak levels during the subsequent 5 -year period. Snag loss approximately balanced snag gain from 1997 to 2002, was lower than snag gain from 2002 to 2007, and exceeded snag gain from 2007 to 2012 (Fig. 4). Consequently, snag abundance changed little from 1997 to 2002, increased significantly in both forest types from 2002 to 2007, and declined slightly from 2007 to 2012. Despite this decline, snag abundance in 2012 remained significantly greater than abundance prior to 2007 in both forest types (Table 4; Fig. 4). Log abundance lagged changes in snag abundance. Mean log abundance increased in both forest types from 2004 to 2014, but as noted earlier, most of that increase occurred between 2004 and 2009, especially in ponderosa pine forest (Tables 2, 3; Figs. 2, 4). The much greater abundance of logs relative to snags largely had 2 causes: greater longevity of logs relative to snags, and the fact that multiple logs can result from a single tree or snag due to breakage.

\section{Discussion}

Many studies have discussed the general impacts of drought and climate change on forest ecosystems (e.g., Boisvenue and Running 2006, Millar et al. 2007, Bonan 2008, Allen et al. 2010), but specific information on trends in log populations following a pulse in droughtmediated tree mortality is lacking. Our results indicated pronounced differences between mixed-conifer and ponderosa pine forest in ubiquity, magnitude, and progression of this pulse in $\log$ inputs. Increases in $\log$ abundance were more widespread across the landscape in mixed-conifer forest, with almost $80 \%$ of mixed-conifer plots showing increased log abundance over the 10-year sampling period, whereas more than half of ponderosa pine plots showed no net change or decreased abundance (Fig. 3). In terms of magnitude, changes in mean log abundance and volume over the period from 2004 to 2014 were respectively more than 8 and 79 times greater in mixed-conifer forest than in ponderosa pine forest (Table 2). This difference was consistent 
TABLE 4. Snag gain (an index of tree mortality, estimated based on new snags recruited), snag loss (falling snags), and snag abundance by time period in northern Arizona mixed-conifer and ponderosa pine forests, based on repeated sampling of 53 and 60 plots, respectively. All units are snags per hectare $\left(\operatorname{snags} \cdot \mathrm{ha}^{-1}\right)$.

\begin{tabular}{|c|c|c|c|c|c|}
\hline \multirow[b]{2}{*}{ Parameter } & \multirow[b]{2}{*}{ Period/year } & \multicolumn{2}{|c|}{ Mixed-conifer } & \multicolumn{2}{|c|}{ Ponderosa pine } \\
\hline & & $\mathrm{M}^{\mathrm{a}}$ & $95 \% \mathrm{CI}^{\mathrm{b}}$ & $\mathrm{M}^{\mathrm{a}}$ & $95 \% \mathrm{CI}^{\mathrm{b}}$ \\
\hline \multirow[t]{3}{*}{ Snag gain } & 1997-2002 & 9.6 & 6.9 to 12.5 & 1.7 & 1.1 to 2.7 \\
\hline & 2002-2007 & 28.7 & 18.7 to 42.3 & 4.0 & 2.7 to 5.9 \\
\hline & 2007-2012 & 9.9 & 7.7 to 12.6 & 1.7 & 1.0 to 2.5 \\
\hline \multirow[t]{3}{*}{ Snag loss } & 1997-2002 & 5.1 & 4.0 to 6.2 & 1.1 & 0.6 to 2.1 \\
\hline & 2002-2007 & 8.6 & 6.4 to 10.3 & 1.4 & 0.9 to 2.3 \\
\hline & 2007-2012 & 14.7 & 9.8 to 21.4 & 3.1 & 1.8 to 5.1 \\
\hline \multirow[t]{4}{*}{ Snag abundance } & 1997 & 29.0 & 23.7 to 34.7 & 5.6 & 4.1 to 7.5 \\
\hline & 2002 & 33.2 & 27.3 to 39.8 & 6.0 & 4.6 to 7.7 \\
\hline & 2007 & 55.8 & 43.8 to 71.6 & 10.3 & 8.1 to 13.7 \\
\hline & 2012 & 53.3 & 42.4 to 69.0 & 9.8 & 7.6 to 12.0 \\
\hline
\end{tabular}

aHuber's M-estimator, a generalized maximum-likelihood estimator that yields robust estimates of central tendency in distributions containing outliers (Huber and Ronchetti 2009). Estimates were computed from 1000 bootstrap iterations.

bias-corrected confidence interval based on 1000 bootstrap iterations.

in direction if not magnitude with the greater tree mortality observed in mixed-conifer forest $(2.0 \%$ per year) versus ponderosa pine forest (0.4\% per year; Ganey and Vojta 2011).

These forest types also differed with respect to temporal progression of this pulse in log inputs. Both mean log abundance and volume increased significantly in both forest types from 2004 to 2009. Those parameters continued to increase significantly in mixedconifer forest from 2009 to 2014 , although more slowly than in the preceding 5 -year period. In contrast, neither parameter increased significantly in ponderosa pine forest from 2009 to 2014 (Tables 2, 3). Thus, log inputs peaked rapidly in both forest types following drought-mediated tree mortality, but particularly in ponderosa pine forest (Fig. 2).

Previous studies of changes in CWD in southwestern forests focused on ponderosa pine forests impacted by a particular disturbance agent such as wildfire (Passovoy and Fulé 2006, Roccaforte et al. 2012) or bark beetle outbreaks (Hoffman et al. 2012, StevensRumann et al. 2012). In contrast, this study included both mixed-conifer and ponderosa pine forests and sampled plots randomly located across a large landscape, including plots impacted by wildfire and bark beetles, as well as plots not impacted by those disturbance agents. The primary advantage here was wider inference, covering the entire droughtimpacted landscape within these forest types rather than particular sites. The primary disadvantage was an inability to attribute observed changes to specific disturbance agents.
The rapid peak in log inputs we observed in ponderosa pine forest was consistent with previous studies, despite the fact that previous studies followed specific disturbances while our plots sampled a landscape subject to multiple disturbance types varying in timing and intensity. For example, previous studies in ponderosa pine forest reported that nearly half of the dead trees fell within 5 years of a bark beetle outbreak (Hoffman et al. 2012), amounts of CWD peaked between 6 and 12 years following wildfire in 2 studies across postfire chronosequences (Passovoy and Fulé 2006, Roccaforte et al. 2012), and $41 \%$ of snags fell within 7 years following a wildfire (Chambers and Mast 2005). The observed rapid peak in log inputs in ponderosa pine forest is also consistent with empirical data on fall rates of snags in this area. Snag populations in ponderosa pine forests were heavily dominated by ponderosa pine snags (Ganey and Vojta 2014), and these snags fall at higher rates than other major species present (Ganey et al. 2015). We know of no previous studies on timing of log inputs for southwestern mixed-conifer forests following disturbance. Our results suggest that log inputs also peaked rapidly following disturbance in this forest type, but not as rapidly as in ponderosa pine forest.

Mean log abundance in 2014, twelve years after the peak drought year that precipitated the pulse in log inputs, was approximately $52 \%$ and $30 \%$ greater than 2004 levels in mixed-conifer and ponderosa pine forest, respectively (Table 2 ). We do not know how long these elevated levels will persist. Two 

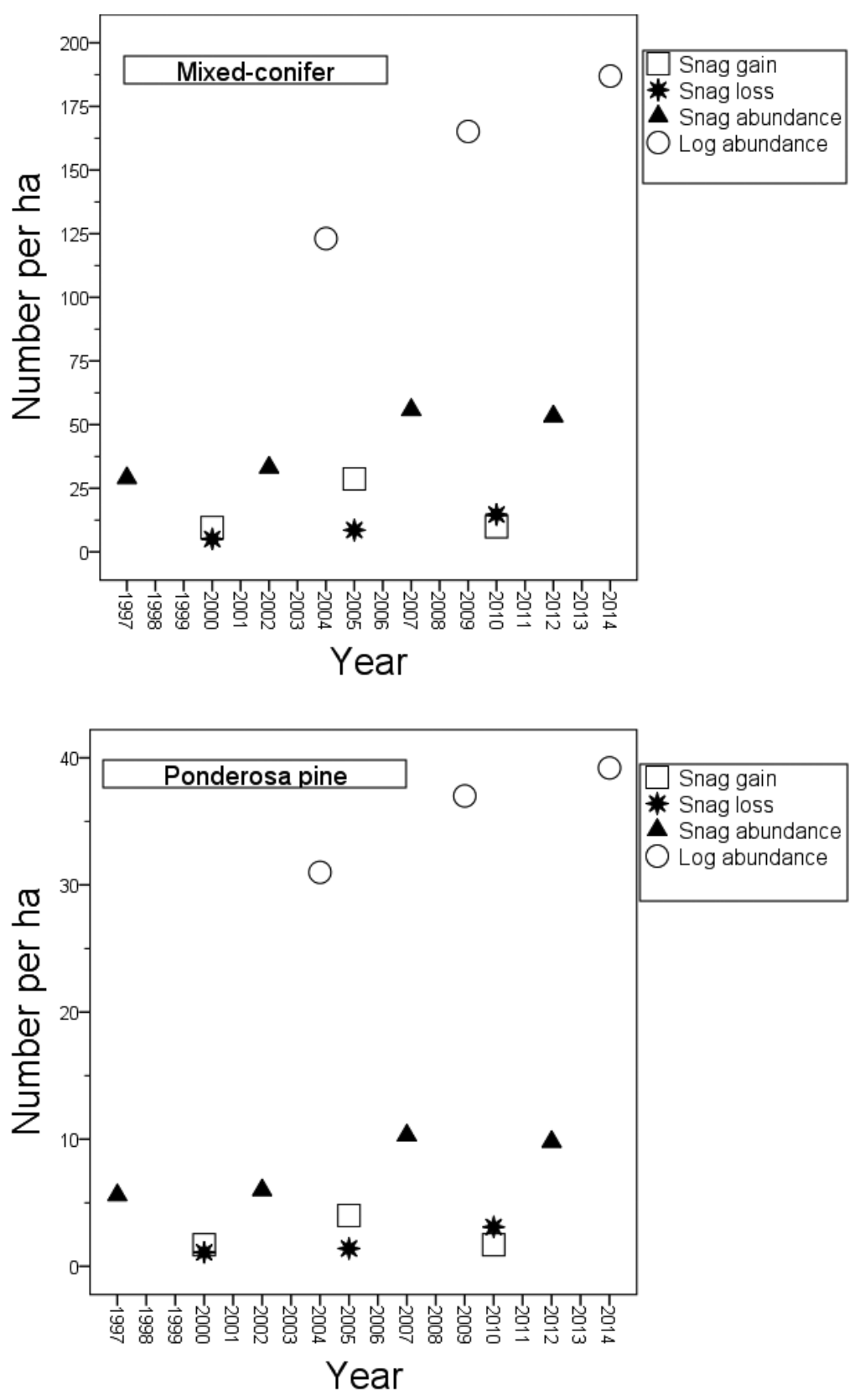

Fig. 4. Point estimates for snag gain, snag loss, snag abundance, and log abundance estimated by time period in northern Arizona mixed-conifer forest (top) and ponderosa pine forest (bottom), based on repeated sampling of 53 and 60 plots, respectively. All units are number per hectare; note that scale of the $y$-axis differs between forest types. Point estimates were based on Huber's M-estimator; bootstrapped, bias-corrected confidence intervals associated with point estimates are shown in Tables 2 and 4. Snag abundance was sampled in 1997, 2002, 2007, and 2012; log abundance in 2004, 2009, and 2014. Snag gain and loss were estimated from snag inventories, with estimates covering the periods 1997 to 2002,2002 to 2007, and 2007 to 2012. Point estimates for snag gain and loss were plotted near the midpoints of those intervals.

studies evaluated CWD levels across a chronosequence of post-fire landscapes in southwestern ponderosa pine forest, but those sequences covered periods of only 18 (Roccaforte et al. 2012) and 27 years (Passovoy and Fulé 2006), and trajectories for CWD levels differed 
between studies. CWD levels peaked relatively quickly in both studies (see above), then declined steadily from that peak in Roccaforte et al. (2012), consistent with theoretical models of CWD dynamics (Harmon et al. 1986). In contrast, CWD levels appeared to reach a plateau that persisted throughout the 27-year chronosequence in Passovoy and Fulé (2006). Reasons for the difference in CWD trends between studies are unknown, but may relate to the specific details of the fires included in the chronosequences.

We know of no comparative data on trends in CWD in southwestern mixed-conifer forest or over periods longer than 27 years in southwestern ponderosa pine forest. Those trends will be driven by the balance between continuing log inputs and loss of logs to decay processes, fire, and fuelwood harvest. Decay rates are likely to be relatively slow in these forest types, especially in ponderosa pine and drier mixed-conifer forests (Harmon et al. 1986). The fact that snag abundance remained greater in 2012 than in predrought years in both forest types suggests that log inputs may continue at levels greater than predrought background levels in the near future. In the absence of fire, log abundance therefore may remain elevated or continue to increase in the near future, especially in mixed-conifer forest, suggesting that our plots may follow a trajectory more similar to the plateau observed by Passovoy and Fulé (2006) than the steady decline from an early peak observed by Roccaforte et al. (2012).

Composition of log populations also will change as this log pulse continues. In both of the ponderosa pine chronosequence studies, CWD populations were dominated by sound CWD in the early postfire years but by rotten CWD in later years, with the transition occurring sometime after 8-9 years post-fire in Passovoy and Fulé (2006) and approximately 16 years post-fire in Roccaforte et al. (2012). These changes have implications for fuels managers, because rotten CWD is more prone to ignition and smoldering than sound CWD (Brown et al. 2003).

Previous authors have voiced concerns regarding elevated fuel loads resulting from disturbance events in ponderosa pine forest (Hoffman et al. 2012, Roccaforte et al. 2012, Stevens-Rumann et al. 2012), but little attention has been given to mixed-conifer forests.
Our results indicate that the increase in fuel loads due to this pulse in log inputs was both far greater and more widespread in mixed-conifer forests than in ponderosa pine forests, suggesting that a greater research and management focus on this forest type may be appropriate.

\section{Conclusions}

Changes in log populations affect fuel complexes, wildlife habitat, and ecosystem services. Despite this, we know little about the dynamics of those populations or about the timing and duration of pulses in log inputs following disturbance events, particularly for southwestern mixed-conifer forests. Our results both complement and extend results from a previous paper on this pulse in log populations (Ganey and Vojta 2012a). They suggest that the 2 forest types studied differed in their dynamics, with log abundance and volume peaking more rapidly in ponderosa pine forest and the magnitude of the increase in log abundance and volume both far greater and more widespread in mixed-conifer forest. Future trends in log numbers will depend on the interplay between fall and breakage rates of remaining and newly formed snags and losses of logs to decay processes, fire, and fuelwood harvest. Because snag densities remained high in both forest types, log numbers may remain elevated or even continue to increase in the near future in both forest types, but especially in mixed-conifer forest. Because decay rates for logs in these systems are not well understood, the duration and ultimate magnitude of this drought-mediated pulse in log inputs remains unknown. Given the response of these forest types to the recent drought (Ganey and Vojta 2011), and the predicted trend toward considerably warmer and drier climate in the southwestern United States (Seager et al. 2007), future pulses of tree mortality like the one observed in this study are likely in these forest types. Understanding how these systems respond to these pulses will aid forest ecologists and managers in adapting management policies to changing future environments (e.g., Millar et al. 2007).

\section{ACKNOWLEDGMENTS}

We thank J. Jenness, G. Martinez, M. Stoddard, B. Strohmeyer, R. White, and especially A. and J. Iniguez for their assistance in 
establishing plots, and D. and N. Ganey and C. Vojta for assistance with sampling plots. For assistance with initial plot selection, we thank J. Ellenwood, B. Higgins, K. Menasco, C. Nelson, and G. Sheppard (Kaibab National Forest), and C. Beyerhelm, A. Brown, H. Green, T. Randall-Parker, C. Taylor, and M. Whitney (Coconino National Forest). L.S. Baggett advised on statistical methods. Comments by 3 anonymous reviewers helped to improve an earlier version of this paper.

\section{Literature Cited}

Acker, S.A., J. Kertis, H. Bruner, K. O'Connell, and J. Sexton. 2013. Dynamics of coarse woody debris following wildfire in a mountain hemlock (Tsuga mertensia) forest. Forest Ecology and Management 302:231-239.

Allen, C.D., A.K. Macalady, H. Chenchouni, D. Bachelet, N. McDowell, M. Vennetier, T. KitZBerger, A. Rigling, D.D. Breshears, E.H. HogG, ET AL. 2010. A global overview of drought and heatinduced tree mortality reveals emerging climate change risks for forests. Forest Ecology and Management 259:660-684.

Boisvenue, C., And S.W. Running. 2006. Impacts of climate change on natural forest productivity-evidence since the middle of the 20th century. Global Change Biology 12:862-882.

BONAN, G.B. 2008. Forests and climate change: forcings, feedbacks, and the climate benefits of forests. Science 320:1444-1449.

Brown, J.K., E.D. Reinhardt, and K.A. Kramer. 2003. Coarse woody debris: managing benefits and fire hazard in the recovering forest. USDA Forest Service General Technical Report RMRS-GTR-105.

Bull, E.L., C.G. Parks, and T.R. Torgersen. 1997. Trees and logs important to wildlife in the interior Columbia River Basin. USDA Forest Service General Technical Report PNW-GTR-391.

Butler, J., K. Alexander, and T. Green. 2002. Decaying wood: an overview of its status and ecology in the United Kingdom and continental Europe. Pages 11-19 in W.F. Laudenslayer Jr., P.J. Shea, B.E. Valentine, C.P. Weatherspoon, and T.E. Lisle, technical coordinators, Proceedings of the Symposium on the Ecology and Management of Dead Wood in Western Forests. USDA Forest Service General Technical Report PSW-GTR-181.

Chambers, C.L., and J.N. Mast. 2005. Ponderosa pine snag dynamics and cavity excavation following wildfire in northern Arizona. Forest Ecology and Management 216:227-240.

Chambers, C.L., AND J.N. Mast. 2014. Snag dynamics and cavity excavation after bark beetle outbreaks in southwestern ponderosa pine forests. Forest Science 60:713-723.

Cunningham, J.B., R.P. BaLda, and W.S. Gaud. 1980. Selection and use of snags by secondary cavity-nesting birds of the ponderosa pine forest. USDA Forest Service Research Paper RM-222.

Dunn, C.J., AND J.D. BAILEY. 2012. Temporal dynamics and decay of coarse woody debris in early seral habitats of dry-mixed conifer forests in Oregon's eastern Cascades. Forest Ecology and Management 276:71-81.

Dunn, C.J., AND J.D. BaILey. 2015. Modeling the direct effects of salvage logging on long-term temporal fuel dynamics in dry-mixed conifer forests. Forest Ecology and Management 341:93-109.

Efron, B., AND R. Tibshirani. 1993. An introduction to the bootstrap. CRC Monographs on Statistics and Applied Probability 57. Chapman \& Hall, Boca Raton, FL. 456 pp.

Forrestel, A.B., B.S. Ramage, T. Moody, M.A. Moritz, AND S.L. STEPhens. 2015. Disease, fuels and potential fire behavior: impacts of sudden oak death in two coastal California forest types. Forest Ecology and Management 348:23-30.

Ganey, J.L., AND S.C. VojTA. 2004. Characteristics of snags containing excavated cavities in northern Arizona mixed-conifer and ponderosa pine forests. Forest Ecology and Management 199:323-332.

Ganey, J.L., and S.C. Vojta. 2005. Changes in snag populations in northern Arizona mixed-conifer and ponderosa pine forests, 1997-2002. Forest Science 51:396-405.

Ganey, J.L., AND S.C. VojTA. 2011. Tree mortality in drought-stressed mixed-conifer and ponderosa pine forests, Arizona. Forest Ecology and Management 261:162-168.

GaneY, J.L., AND S.C. VojTA. 2012a. Rapid increase in log populations in drought-stressed mixed-conifer and ponderosa pine forests in northern Arizona. Open Journal of Forestry 2(2):59-64.

GaneY, J.L., AND S.C. VoJTA. 2012b. Trends in snag populations in drought-stressed mixed-conifer and ponderosa pine forests, 1997-2007. International Journal of Forest Research Article ID 529197:1-8. http://dx.doi.org/10.1155/2012/529197

GANEY, J.L., AND S.C. VoJTA. 2014. Trends in snag populations in northern Arizona mixed-conifer and ponderosa pine forests, 1997-2012. USDA Forest Service Research Paper RMRS-RP-105.

Ganey, J.L., G.C. White, J.S. Jenness, and S.C. Vojta. 2015. Mark-recapture estimation of snag standing rates in northern Arizona mixed-conifer and ponderosa pine forests. Journal of Wildlife Management 79:1369-1377.

Harmon, M.E., J.F. Franklin, F.J. Swanson, P. Sollins, S.V. Gregory, J.D. Lattin, N.H. Anderson, S.P. Cline, N.G. Aumen, J.R. Sedell, ET AL. 1986. Ecology of coarse woody debris in temperate ecosystems. Advances in Ecological Research 15:133-302.

Hoffman, C.M., C.H. Sieg, J.D. McMillin, and P.Z. FulÉ. 2012. Fuel loadings five years after a bark beetle outbreak in southwestern USA ponderosa pine forests. International Journal of Wildland Fire 21:306-312.

Huber, P.J., AND E.L. Ronchetti. 2009. Robust statistics. 2nd edition. John Wiley \& Sons, Inc., Hoboken, NJ.

Kane, J.M., T.E. Kolb, and J.D. MCMillin. 2014. Standscale tree mortality factors differ by site and species following drought in southwestern mixed-conifer forests. Forest Ecology and Management 330:171-182.

Maser, C., AND J. Trappe. 1984. Seen and unseen world of the fallen tree. USDA Forest Service General Technical Report PNW-164.

McComb, W., And D. LindenmaYer. 1999. Dying, dead, and down trees. Pages 335-372 in M.L. Hunter Jr., 
editor, Maintaining biodiversity in forest ecosystems. Cambridge University Press, Cambridge, United Kingdom.

Millar, C.L., N.L. Stephenson, and S.L. Stephens. 2007. Climate change and forests of the future: managing in the face of uncertainty. Ecological Applications 17:2145-2151.

Negrón, J.F., J.D. McMillin, J.A. Anhold, And D. CoulSON. 2009. Bark beetle-caused mortality in a droughtaffected ponderosa pine landscape in Arizona, USA. Forest Ecology and Management 257:1353-1362.

Passovoy, M.D., AND P.Z. Fulé. 2006. Snag and woody debris dynamics following severe wildfires in northern Arizona ponderosa pine forests. Forest Ecology and Management 223:237-246.

Peterson, D.W., E.K. Dodson, and R.J. Harrod. 2015. Post-fire logging reduces surface woody fuels up to four decades following wildfire. Forest Ecology and Management 338:84-91.

RocCaforte, J.P., P.Z. Fulé, W.W. ChanCELlor, and D.C. LaUGHLIN. 2012. Woody debris and tree regeneration dynamics following severe wildfires in Arizona ponderosa pine forests. Canadian Journal of Forest Research 42:593-604.

Seager, R., M.F. Ting, I.M. Held, Y. Kushmir, J. Lu, G. Vecchi, H. Huang, N. Harnick, A. Leetmaa, N. Lau,
ET AL. 2007. Model projections of an imminent transition to a more arid climate in southwestern United States. Science 316:1181-1184.

Shorohova, E., and E. Kapitsa. 2015. Stand and landscape scale variability in the amount and diversity of coarse woody debris in primeval European boreal forests. Forest Ecology and Management 356: 273-284.

Stevens-Rumann, C.S., C.H. Sieg, and M.E. Hunter. 2012. Ten years after wildfires: how does varying tree mortality impact fire hazard and forest resiliency? Forest Ecology and Management 267:199-208.

Weiss, J.L., C.L. Castro, and J.T. Overpeck. 2009. Distinguishing pronounced droughts in the southwestern United States: seasonality and effects of warmer temperatures. Journal of Climatology 22:5918-5932.

Woldendorp, G., and R.J. KeEnan. 2005. Coarse woody debris in Australian forest ecosystems: a review. Austral Ecology 30:834-843.

Received 12 January 2017 Accepted 16 May 2017 Published online 16 August 2017 